\title{
TERMINOLOGY OF THE PROFESSIONAL COMPONENT OF FORMING THE READINESS OF FUTURE BACHELORS IN PHYSICAL CULTURE AND SPORTS FOR COACHING
} ТЕРМІНОЛОГІЯ ПРОФЕСІЙНОЇ СКЛАДОВОЇ ФОРМУВАННЯ
ГОТОВНОСТІ МАЙБУТНІХ БАКАЛАВРІВ $З$ ФІЗИЧНОЇ КУЛЬТУРИ
ТА СПОРТУ ДО ТРЕНЕРСЬКОЇ ДІЯЛЬНОСТІ

In the article we have analyzed the basic definitions of the professional component of forming the readiness of future bachelors in physical culture and sports for coaching. It has been determined that the readiness of future bachelors in physical culture and sports for coaching is a specially prepared educational process, which is aimed at forming the readiness of future professionals to carry out professional activity in the field of physical culture and sports. By "forming the readiness of future bachelors in physical culture and sports for coaching» we mean a specialized professional education, where the formation of knowledge and skills of students of the specialty "Physical culture and sports" through the development of ideological, motivational, psychosomatic, professional and didactic competences, forming a value attitude towards coaching for successful self-realization as a future coach. We have established that "the readiness of future bachelors in physical culture and sports for coaching" is a multidimensional concept, which is: a set of formed value units that will allow for rapid adaptation and selfdevelopment in future professional activity; a set of psychomotor skills and psychosomatic properties that will enable the future professional activity to be qualified; cognitive competencies that will help to base in future professional activity on the best experience of the theory and methodology of physical culture, the theory and methodology of the chosen sport, psychology and pedagogy; effective professional stereotypes that will allow the organization of sports-training and training activities of young athletes on a reflective basis; an integrative set of professional and personal qualities and a certain mental state of the future specialist, which reflects the formation of the sports-pedagogical mentality.

Key words: readiness formation, future bachelors in physical culture and sports, coach, coaching.

У статті нами проаналізовано основні дефрініції фрахового складника формування готовності майбутніх бакалаврів з фрізичної культури і спорту до тренерської діяльності.
Було визначено, що підготовка майбутніх бакалаврів з фрізичної культури і спорту до тренерської діяльності - че спеціально підготовлений освітній прочес, який спрямований на формування у майбутніх фрахівиів готовності до ефрективного здійснення професійної діяльності в галузі фрізичноі культури та спорту. Під поняттям «орормування готовності майбутніх бакалаврів з фрізичної культури і спорту до тренерської діяльності» ми розуміємо спеціалізовану професійну освіту, де відбувається фрормування знань, умінь та навичок студентів спеціальності «Фізичне виховання і спорт» шляхом розвитку світоглядних, мотиваційних, психосоматичних, фрахових та дидактичних компетентностей, формування ціннісного ставлення до тренерської діяльності для успішної самореалізації як майбутнього тренера. Нами встановлено, що підготовленість майбутніх бакалаврів з фрізичної культури і спорту до тренерської діяльності - це багатоаспектне поняття, яке є сукупністю сорормованих ціннісних установок, що забезпечать їм можливість швидкої адаптаuіï й саморозвитку в майбутній професіійній діяльності; комплексом психомоторних навичок і психосоматичних властивостей які дадуть можливість кваліфріковано здійснювати майбутню професіійну діяльність; когнітивними компетентностями, що допоможуть спиратися в майбутній профресійній діяльності на кращий досвід теорії й методики фрізичного виховання, теорії і методики обраного виду спорту, психологіі та педагогіки; ефективними профресійними стереотипами, що дадуть можливість організовувати спортивно-тренувальну та навчально-тренувальну діяльність юних спортсменів на рефлексивній основі; інтегративною сукупністю профресійних і особистісних якостей та певним психічним станом майбутнього фрахівця, у якому відбивається сорормованість спортивно-педагогічного менталітету

Ключові слова: формування готовності майбутні бакалаври з фрізичної культури і спорту, тренер, тренерська діяльність.
Formulation of the problem in general. At the present stage of development of our country due to the pedagogical science the search of the new models of training for future specialists in the field of "Physical Culture and Sports" is being carried out. Human development is a complex process that lasts for a lifetime. Particularly, there is intense during his youth and student's life. The quality of professional training of the future specialist and his / her further professional activity and development during life depend on the process of formation and development of personality in the student age. Many scholars have explored this problem, in particular, scientists O. Voitovskaya and $\mathrm{S}$. Tolochko. They analysed the lifelong learning as a culture, which is considered by the authors as a set of educational technologies used for self-education, self-development and self-improvement of personality throughout life [16, p. 146].

Analysis of recent research and publications. The problems of Olympic sports were investigated by (V. Platonov); theories and methods of gradual training of athletes by (G. Arzyutov); theoretical and methodological aspects of the implementation of functional reserves of athletes of higher qualification by 
(M. Bulatova); psychological foundations of the professional formation of the coach-teacher by (N. Volyanuk); didactic principles of optimization of the training process in the system of training athletes by (O. Deminski); theoretical and methodological foundations of forming a system of sport for all in Ukraine by (M. Dutchak); theoretical and methodological foundations of the technology of training future specialists in complex-coordination sports by (I. Medvedeva); management of training and competitive loads of high-class athletes in the conditions of intensification of the training process by (Yu. Shkrebtiy).

Highlighting previously unresolved parts of a common problem. However, the issue of shaping the willingness of future bachelors in physical culture and sports for coaching remains poorly understood.

The purpose of our work is to analyze the main definitions of the professional component of forming the readiness of future bachelors in physical culture and sports for coaching.

Outline of the main research material. Let us analyze the main definitions of the professional component of forming the readiness of future bachelors in physical culture and sports for coaching (Pic. 1).

In the Great explanatory dictionary of modern Ukrainian language, the term "preparation" is generally defined as a store of knowledge, skills, experience acquired in the process of learning, practical activity [2, p. 952]. We fully agree with the definition of "professional training", which is presented in the Encyclopedia of Education, which is interpreted as a complex systematic characteristic, which defines the process and result of becoming a person as a subject of professional activity through the accumulation of value-meaningful experience of solving educational and professional problems on the bases of their own professional position [9, p. 456].

However, in our opinion, ordinary professional training does not automatically provide for the accumulation and formation of valuable meaningful professional experience for the future coaches. This is due to a number of circumstances, one of which is the specificity of teaching sports. Therefore, during our own research and observations, we are convinced that the preparation of future bachelors in physical culture and sports for coaching is a specially prepared educational process, which aims at the formation of future specialists of readiness for the effective exercise of professional activity in the field of "Physical culture and sports". By "forming the readiness of future bachelors in physical culture and sports for coaching" we mean a specialized professional education, where the formation of knowledge and skills of students of the specialty "Physical culture and sports" through the development of ideological, motivational, psychosomatic, professional and didactic competences, forming a value attitude towards coaching activities for successful self-realization as a future coach.
An important aspect in the professional training of a future specialist is readiness. In V. Dal's dictionary, "readiness" is defined as the state or properties of a person who is ready, adapted to something who can and wants to perform a certain action [4, p. 388].

M. Dyachenko and L. Kandybovich consider the notion of «readiness» as professionally important quality, mental state of personality, set of beliefs, attitudes, motives, feelings, volitional and intellectual qualities, knowledge, abilities, skills, a setting on active, expedient, purposeful actions [7, p. 18]. According to K. Durai-Novakova's theoretical position, readiness is the result of professional training that begins with professional self-determination, professional education, development, self-education [6, p. 45].

Therefore, in our opinion, preparedness is a set of ideological, motivational, psychosomatic, professional and didactic competences, which in their potential basis ensure a successful transition from educational to professional activity. Preparedness is conditioned by the development of psychomotor and cognitive components of the future coach's personality. In turn, preparedness for professional activity is a state of potential readiness and ability for conscious active dynamic interaction of a future specialist in primary positions, which does not require from the graduate of the educational institution to have previous experience of professional practical activity.

Therefore, "the preparedness of future bachelors in physical culture and sports for coaching" is a multidimensional concept, which is: a set of formed value units that will allow for rapid adaptation and self-development in future professional activity; a set of psychomotor skills and psychosomatic properties that will enable the future professional activity to be qualified; cognitive competencies that will help to base in future professional activity on the best experience of the theory and methodology of physical culture, the theory and methodology of the chosen sport, psychology and pedagogy; effective professional stereotypes that will allow to organize the sports-training activities of young athletes on a reflective basis; an integrative set of professional and personal qualities and a certain mental state of the future specialist, which reflects the formation of the sports-pedagogical mentality.

According to $\mathrm{O}$. Leontiev, human activity has a complex hierarchical structure. It consists of several levels. The upper level is the level of special activities, followed by the level of action, followed by the level of operations, and the lowest - the level of psychophysiological functions. According to a well-known psychologist, an activity, as opposed to a simple performance action, should have a certain vital meaning for the person, which is provided only if it has a purpose that completely coincides with the basic motive of its behavior in a certain situation [11, p. 4]. 
Comparing educational and professional activity, according to M. Levkivsky, in the traditional sense, these are fundamentally different realities, because in the transition from training to work the activity is not limited to the simple application of knowledge in practice [10, p. 16]. In the first case, knowledge acts as the subject of activity, in the second case, a holistic complex of knowledge and skills acquired during the course of training is transformed into a powerful tool for further solving problems arising in the field of specialization. V. Shadrykov's scientific views make it possible to consider professional activity as a system of really existing facts - a set of phenomena, processes, events, states, human experience, connected with the development of professional qualities, becoming a specialist, his professional activity [15, p. 80].

In our work, professional activity becomes a conscious, active, dynamic system of interaction of the future coach, where he deliberately achieves the specified goals that arise due to him to meet certain needs. By future coach, we understand the individual as a carrier of desire, willingness and ability to perform activities; the carrier's ability to be responsible for its emergence, implementation and development; a carrier of the ability to be the creator of one's professional activity. Therefore, the professional activity of a future coach is a conscious psychomotor and cognitive activity of a sports teacher aimed at designing and implementing the tasks of educational, training and educational processes.

The beginning of the study of the problem of "readiness for activity" in foreign and domestic psychological and pedagogical science falls on the post-war period - 50-60 years. [7, p. 67]. In our study we will use the notion of "readiness for activity" as a certain state of mobilization of the psychological and psychophysiological systems of a person, which ensure the performance of certain activities.

V. Semichenko believes that readiness for professional activity is a psychological condition, which includes: operational readiness - immediate pre-start activation of a person, his inclusion at the required level in the activity; functional readiness - the per-

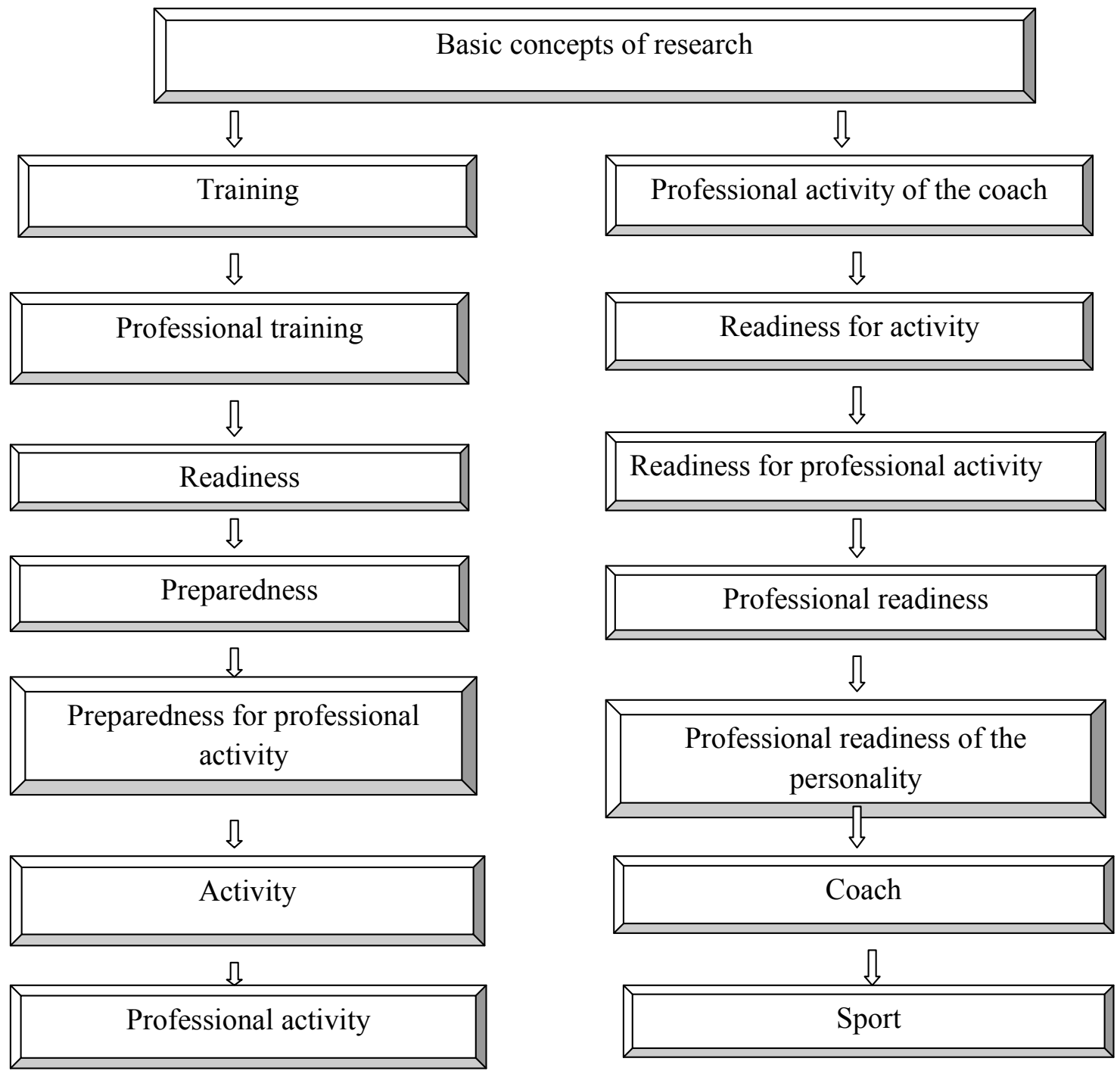

Pic. 1 
son's awareness of his goals, determination of the most likely ways of action; personal readiness, which includes prolonged high activity of the person at inclusion in the labor process, forecasting of necessity and distribution in time of motivational, volitional, intellectual efforts, estimation of probability of achievement of life successes through activity [13, p. 99].

In our understanding, the readiness for professional activity becomes a multifaceted systemic concept, which is the totality of professional competence, the formation of personal and professional qualities of a future specialist and characterizes his certain mental state.

Professional readiness is also an important concept of our work. There are three main approaches to modern professional readiness research: functional, personal, and functional-personal. Within the functional approach, professional readiness is considered as a certain functional state of psychological readiness, which is related, first of all, to the setting for professional activity [7, p. 45]. Personal approach defines professional readiness as a personal formation, which is a set of personally important professional properties and the result of professional training [8, p. 43]. Functional-personal approach recognizes professional readiness by integrated education, encompassing professionally significant qualities, set of necessary knowledge and skills necessary for this activity [5, p. 22].

Therefore, in our opinion, the category "professional readiness" is both the purpose and the result of training specialists for professional activity, and the content of professional readiness is a criterion for the diagnosis of the training process. The quality of training depends on the level of readiness of the specialist to perform future professional functions. Thus, the professional readiness of future coaches is characterized by an integrative state of personality that combines an optimal system of knowledge, skills, motivations, abilities and personal qualities.

According to A. Tretyak, the professional readiness of the future coach should be given a priority because it is a key figure in the training of a young athlete [14, p. 263]. Professional readiness as a process has the following levels: worldview, the purpose of which is to develop the professional consciousness and self-consciousness of future specialists; professional, aimed at mastering the necessary system of knowledge, strategy and tactics of practical activity of the future teacher, formation of his psychological and pedagogical culture; personal, the purpose of which is the formation of students of professionally significant personality traits, humanistic orientation, "dialogical" as a central component, the ability to professional identification [14, p. 263].

One of the main concepts of our research is the word "coach". In our study, we consider the concept of "coach" as a person who has the appropriate physical and professional training skills to conduct training activities in a particular sport, which is aimed at the formation and improvement of specific theoretical and practical knowledge, skills and physical skills of young athletes, their development prospects.

An important role in shaping the willingness of future bachelors in physical culture and sports for coaching is played by an understanding of the definition of «sport» as an integral part of the physical culture system of the individual, aimed at its comprehensive harmonious development and promotion of health. The purpose of any sport is not only to promote health, overall physical development, but also to achieve high results and victories in sports competitions [3, p. 317]. We consider the notion «sport» as a particular activity of the person, where he is constantly engaged in, seeking not only to temper physical but also mental health and to achieve some success, having excellent training, in the chosen sport.

Conclusions. Thus, we have analyzed the main definitions of the professional component of forming the readiness of future bachelors in physical culture and sports for coaching activities.

\section{REFERENCES:}

1. Бабанский Ю.К. Оптимизация процесса обучения: общедидактический аспект. Москва : Педагогика, 1977. 254 с.

2. Великий тлумачний словник сучасної української мови / головний редактор В.Т. Бусел. Київ ; Ірпінь : Перун; 2005. 1728 с.

3. Гончаренко С.У. Український педагогічний словник / голов. ред. С. Головко. Київ : Либідь, 1997. $376 \mathrm{C}$.

4. Даль В.И. Толковый словарь живого великорусского языка : в 4 т. Москва : Русский язык, 1989. T. $1.699 \mathrm{c}$.

5. Данилко М. Сучасні уявлення про сутність і структуру діяльності тренера. Фізичне виховання, спорт і культура здоров'я у сучасному суспільстві : зб. наук. пр. Волин. нац. ун-ту ім. Лесі Українки. Луцьк : Волин. нац. ун-т ім. Лесі Українки, 2010. № 2 (10). С. 22-26.

6. Дурай-Новакова К.М. Формирование профессиональной готовности студентов к педагогической деятельности : дисс. ... докт. пед. наук : 13.00.04. Москва, 1983. 353 с.

7. Дьяченко М.И. Психологические проблемы готовности к деятельности. Минск : БГУ, 1976. 176 с.

8. Зеер Э.Ф. Личностно-ориентированное профессиональное образование: теоретико-методологический аспект. Екатеринбург : Изд-во Урал. гос. профр.-пед. ун-та, 2001. 51 с.

9. Енциклопедія освіти. Акад. пед. наук України / голов. ред. В.Г. Кремень. Київ : Юрінком Інтер, 2008. 1040 C.

10.Левківський М.В. Нові навчальні технології. Вісник Житомирського державного університету імені Івана Франка. 1999. № 3. С. 14-18. 
11. Леонтьев А.А. Что такое деятельностный подход в образовании. Начальная школа. Плюс. Минус. 2001. № 1. С. 3-6.

12. Новий тлумачний словник української мови / уклад. В. Яременко, О. Сліпушко. 2-ге вид., випр. Київ : Аконіт, 2001. Т. 3. 927 с.

13. Семиченко В.А. Проблемы мотивации поведения и деятельности человека. Модульный курс психологии. Модуль «Направленность» (лекции, практические занятия, задания для самостоятельной работы). Київ : Миллениум, 2004. 521 с.
14.Третьяк А.Н. Модель деятельности и личности современного тренера-преподавателя. Педагогіка, психологія та мед.-біол. пробл. фріз. виховання і спорту : наук. журнал. Харків, 2009. № 5. С. 263-265.

15. Шадриков В. Д. Психология деятельности и способности человека : учеб. пособ. для вузов. Москва : Логос, 1996. 320 с.

16. Voitovska O., Tolochko S. Philosophy and Cosmology Lifelong Learning as the Future Human Need. Philosophy and Cosmology. Volume 22, 2019. C. 145-151. 